\title{
Effect of Business Performance on Taxation of Small and Medium Enterpries Scale in Bwari Area Council FCT Abuja, Nigeria
}

\author{
Israel O. E. Idewele \\ Department of Banking and Finance, Veritas University, Abuja, Nigeria \\ idewelei@gmail.com
}

\section{Abstract}

Tax remains a veritable means of developing a modern day economy and apart from the major sources of taxes such as Company Income Tax, Value Added Tax and Withholding-Tax. Apart from these taxes there is also taxation of the informal sector such as the SMEs. This study investigated the effects of business performance on taxation of Small and Medium Enterprise scale (SMEs) in Bwari Area Council FCT, Abuja. The study had a population of 156 and a sample size of 112 which was arrived at using Yamane sampling model. Data was gathered using questionnaires administered to the respondents and was analyzed using multiple regression technique. The findings revealed that return on assets and staff recruitment had positive and significant effect on taxation of SMEs in Bwari Area Council of FCT, Abuja. It was recommended amongst others that SMEs should engage in cost saving measures to boost their profits which encourage payment of taxes. It was also recommended that SMEs should employ optimally, their required numbers of staff to boost payment of taxation to Bwari Area Council FCT, Abuja
Keywords

taxation; business performance; small and mediumenterprise scale(SMEs); Buari Area Council FCT Abuja

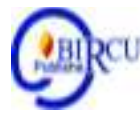

\section{Introduction}

The focus of this research is to examine the effect of taxation on performance of small Medium enterprise scale (SMEs) and therefore the importance of taxes to the Nigerian economy, to ascertain the link between program and therefore the growth of small and medium enterprise scale SMEs in Bwari government of Federal Capital Territory (FCT) Abuja. Although there's a general perception that tax is a crucial source of fund for development of the economy and provision of social services, the issues faced are within the area of negative relationship between taxes and therefore the business' ability to sustain itself and to expand. Small medium enterprise scale (SMEs) are faced with the matter of high tax rates, performance of taxation, complex tax regulations and lack of proper enlightenment or education about tax related issues. Not minding other challenges that tiny medium enterprise scale (SMEs) face in other developing countries like Nigeria; inadequate capital, poor technical and managerial skills, environmental effects and government regulations which affect the operation of small medium enterprise scale (SMEs), In Nigeria the difficulty of multiple taxation take large chunk of revenues generated by these small medium enterprise scale (SMEs) for his or her growth and survival. These have led to increase in record of death of Small and Medium Enterprise scale (SMEs), in Nigeria including Bwari Area Council FCT, Abuja. In Nigeria, most studies conducted on the world of taxation like Patrick \& Chiedu 
(2016); Okwara \& Amori, (2017) and Manukaji (2018).are on the results of taxation on the expansion of the Nigeria economy as a full. Consequently, there's dearth of studies investigating effects of business performance on taxation of SMEs in Nigeria and by extension Bwari Area Council FCT, Abuja and this presents a distinct segment to be filled by this study. Objectives of the Study. The most objective of this study is to seem at the results of business performance on taxation of Small and Medium Enterprise scale (SMEs) in Bwari Area Council FCT, Abuja.

The specific objectives include to:

- Examine the results of asset growth on taxation of Small and Medium Scale Enterprises in Bwari Area council FCT, Abuja

- Investigate the results of return on assets on taxation of Small and Medium Scale Enterprises in Bwari Area council FCT, Abuja

- Assess the results of assets on taxation of Small and Medium Scale Enterprises in Bwari Area council FCT, Abuja

- Evaluate the results of staff recruitment on taxation of Small and Medium Scale Enterprises in Bwari Area council FCT, Abuja.

The researcher was guided by the subsequent set of questions: To what extent does asset growth affect taxation of SMEs in Bwari Area council FCT, Abuja? To what extent does the return on assets affect taxation of SMEs in Bwari Area council FCT, Abuja? To what extent do assets affect taxation of SMEs in Bwari Area council FCT, Abuja? To what extent does staff recruitment have effect on taxation of SMEs in Bwari Area council FCT, Abuja? The following research hypotheses were formulated in Null form as follows: Ho1 Asset growth has no significant effect on taxation of SMEs in Bwari Area council FCT, Abuja. Ho2 Return on assets has no significant effect on taxation of SMEs in Bwari Area council FCT, Abuja. Ho3 assets has no significant effect on taxation of SMEs in Bwari Area council FCT, Abuja. Ho4 Staff recruitment has no significant effect on taxation of SMEs in Bwari Area council FCT, Abuja.

\section{Review of Literature}

\subsection{Concepts of SMEs}

Small and Medium-Scale Enterprises are generally privately owned organisations setup for the purposes of producing goods or services for profit. SMEs have generally been acknowledged as the bedrock of the industrial development of any country. Apart from the numerous goods and services produced by SMEs, they provide a veritable means of large employment, as they are usually labour intensive. They also provide training grounds for entrepreneurs even as they generally rely on the use of local raw materials and if well managed SMEs can gradually transform into giant corporations of tomorrow.

The criteria for categorizing business enterprises under SMEs vary from country to country (Aremu\& Adeyemi, 2011). The identifiable and predominant criteria across the globe include: size of capital invested, number of staff or employees, size of turnover or sales volumes and value of assets (Bureau of statistics, 2001). Relying on the number of employees/staff criterion for instance, some countries describe all enterprises that have less than 100 employees as SMEs, others are in favour of 50 employees and some expand the net to include all firms who have less than 200 employees (Ojeka \& Mukaro, 2011). Besides the controversy in defining the SME using the number of employees, there exist difficulties in other criteria. It becomes apparent that for SME to be defined using the criteria; employees, sales volumes, assets employed, capital invested or a combination of the above, care must be exercised to overcome these inherent difficulties. This view was supported by Ezeife (1988) 
who pointed out that definition based on number of workers may be misleading because owing to improvement in technology, so much money may be involved (say up to I billion naira) when only few people are employed. Ezeife (1988) also pointed out that definition based on capital should consider the time and the place. To buttress this fact, we refer to SME definition by the European Union as follows: 'the new category of small and mediumsized enterprises (SMEs) is made up of enterprises which employ fewer than 250 persons and which have an annual turnover not exceeding 50 million euro, and/or an annual balance sheet total not exceeding 43million euro (Gunter, 2005).

\subsection{Concepts of Taxation of SMES}

Taxation is a compulsory transfer or Payment of money from private individuals, institutions, and corporations to the government. Anyanwu (1997) noted that taxation has three Principal objectives, which are regulation of the economy and economic activities, raising of revenue for the govt and controlling of income and employment. Tax bases simply are those objects upon which tax income are derived; (Mansfield 1973). Tax is the major source of revenue for the government and as such government makes effort towards maximizing tax revenue. But, to the extent that government tries to maximize tax revenue, consideration of tax effects on economic agents that pay the tax should not be over looked. To this extent, Bhat (1973) opined that what matters in government policies including tax policy is to frame them to induce rapid growth with social justice, and at the same time to ensure that they are simple, easily intelligible and are not likely to change in an ad hoc, unprincipled manner. Anyanwu (1997) contended that the presence of tax distorts the Pattern of production, consumption, investment, employment and other similar patterns for good or for bad and these distortions are collectively viewed as the effects to taxation. Oyebode (2010), points out that while global economic recovery can be perceived at the macro and micro level, taxation could be an important instrument of achieving of consolidating the gain of economic recovery. Thus, it's evident that an honest tax structure plays many roles within the process of economic process of any nation like Nigeria (Appah, 2010). Musgrave and Musgrave (2006) maintained that these roles include: the extent of taxation affects the extent of public savings and thus the quantity of resources available for and Tasie (2013) explained that a system of tax incentives and penalties could also be designed to influence the efficiency of resource utilization; the distribution of the tax burdens plays an outsized part in promoting an equitable distribution of the fruit of economic development; the tax treatment of investment from abroad may affect the quantity of capital inflow and rate of reinvestment of earnings there from; and therefore the pattern of taxation on imports relative thereto of domestic producers affect the foreign balance of trade . Nwezeaku (2005) opined that the scope of these functions will depend on: on the political and economic orientation of the people.

\subsection{Theories of Taxation}

The quest for the optimum taxation rate where tax revenues are maximised for welfare and economic process has been the essence of the varied theories. we have the school theory of taxation, the benefit theory of taxation, the taxable capacity theory and therefore the tax theory system theory, some researchers have attempted to resolve the conceptual distinction between theory and application. Theories of taxation have the objectives of assisting the systematic resolution of practical problems surrounding government financing through exercising the fiscal muscles of taxation 


\subsection{Empirical Studies}

Asset growth and Taxation

According to Tomlin (2008), economists argue that the resources of smaller companies direct towards tax compliance are resources that would rather be used for reinvestment, facilitating future growth. Hence, there's a belief that taxes and a posh legal system put disproportionate pressure on smaller businesses. Small taxpayers under the regular system of taxation are discriminated against, since the compliance requirements, cost of compliance and rate are an equivalent for both small and enormous enterprises. Reducing the compliance costs and rate increases the tiny enterprises margin of profit. It also increases the Government's tax income, since the simplified provisions for a micro enterprise historically reduce the dimensions of the shadow economy and therefore the number of non-complying registered taxpayers(Vasak,2008). Furthermore, SMEs usually need to operate in an overbearing regulatory environment with the plethora of regulatory agencies, multiple taxes, cumbersome importation procedure and high port charges that constantly exert serious burden on their operations. Many SMEs need to affect myriad of agencies at great cost as stated earlier they're heterogeneous and these differences in size and structure may successively carry differing obligations for record-keeping that affect the prices to the enterprises of complying with (and to the revenue authorities of administering) alternative possible tax obligations Public corporations, for instance, commonly have stronger accounting requirements than do sole proprietorships, and enterprises with employees could also be subject to the complete panoply of requirements related to withholding labour income taxes and social contributions (International Tax Dialogue 2007). A poorly executed legal system also results in low efficiency, high collection charges, waste of your time for taxpayers and therefore the staff, and therefore the low amounts of received taxes and the deviation of optimum allocation of resources (Farzbod, 2000). when scaled by sales or assets, the compliance costs of SMEs are above for giant businesses (Weichenrieder, 2007), Among the factors militating against SME tax compliance with are: high tax rates, Low efficiency, high collection charges, waste of your time for taxpayers and therefore the staff, and therefore the refore the low amounts of received taxes and the deviation of optimum allocation of resources (Farzbod, 2000). Others consistent with Yaobin, (2007) are double taxation, no professional tax consultancy, weak tax planning, high taxation cost. Rosen, Carroll and Douglas (2001) analysed the personal income tax returns of a large number of sole proprietors in kenya before and after the tax reform act of 1986 and determined how the substantial reductions in marginal tax rates related to that law affected the expansion of their firms as measured by gross receipts. A study by Ojeka (2011) on tax program and therefore the Growth of SMEs. Found that tiny and enterprises play a really important role in development of the Nigeria economy, making up about $97 \%$ of the whole economy. The research work sought to establish if any relationship exists between the growth of SMEs and the tax policy in Nigeria. It was found that the majority SMEs surveyed were faced with the matter of high tax rates, multiple taxation, complex tax regulations and lack of proper enlightenment or education about tax related issues

\subsection{Staff Recruitment and Taxation}

Derwent (2000) in a case study on taxation behaviour in five different countries (USA, Gambia, Nigeria, South Africa and Kenya), concluded that increased tax burden is a major threat. The results show that the increase in tax rates leads to higher production, distribution and selling costs which lead to higher prices and as a result consumers change their buying behaviour. People react to the higher prices by buying less of the product. When sales fall, some manufactures cut back on production and some workers may lose their jobs. The 
productive resources i.e. land; capital, labour and entrepreneurship are allocated to other industries or go unused. For instance when the government increases taxes on items such as beer and cigarettes for the purpose of realizing revenue and discouraging their consumption people tend to buy local brews. The study recommends government should provide motives for technological progress and innovation that can lower production costs and help firms surpass structural and strategic advantages more effectively. SMEDA (2007), in survey study on basic situation of SME and their support structures in Pakistan with objectives to find out basic situation of SME and their support structures, to determine short term and Long term issues. The study found out that SMEs encounter an increasing complex legal, tax and administrative environment, both in starting and developing their business. According to research, $67 \%$ of small business list tax regulations as most problematic, while $28 \%$ of SMEs felt that taxes in the country are too high. It also found that the present tax structure and administration generally distort incentives and discriminate against small firms. Smaller firms found tax related issues more restrictive than larger firms, 69\% of firms; whose size was less than 1 million faced the greatest of tax related problems. Many small firms claim it is not possible for them to maintain books as per law or hire a professional due to cost constraints. The study recommends government coordination and regular information exchange mechanism among institutions for collective SMEs development. Onias, Mayani, Hove, Chinseri and Mundzura (2014) adopted a descriptive research design to assess the effectiveness of presumptive tax collection system and its impact on the viability of SMEs to grow and recruit more workers in Zimbabwe, Using 67 Bindura commuter transport operators as respondents to the case study. The major objectives of the study were to establish the reason(s) why SMEs are subject to presumptive tax, whether there was any relationship between viability of SMEs and the payment of presumptive tax and the effectiveness of Zimbabwe Revenue Authority's tax awareness campaigns. 67.5\% of the respondents agreed that presumptive tax negatively affected their profits and $7.5 \%$ were not sure. Only $25 \%$ said presumptive tax did not affect their profits. This suggests an inverse link between presumptive tax and viability of SMEs. Major recommendations included intensification of presumptive tax awareness campaigns and involvement of taxpayers in setting up tax amounts.

\section{Research Methods}

The main objective of the study is to examine the effect of business performance on taxation of SMEs in Bwari Area Council of FCT, Abuja. Survey design was adopted for the study.

The population of this study is one hundred and fifty six (156). This figure was obtained from the Bwari Area Council Secretariat for the year 2018. The researcher adopted the Taro Yamane's formula to obtain the sample size which is demonstrated as follows;

Formula: Sample size $\mathrm{n}=(\mathrm{N})$

$$
1+\mathrm{N}(\mathrm{e}) 2
$$

Where $\mathrm{N}=$ Population (156), $\mathrm{n}=$ sample size (Unknown), $\mathrm{e}=$ level of significance $(5 \%), 1=$ Constant,

Therefore, Sample size $n=$

$$
\begin{array}{cll}
(156) & = & 156=112 \\
1+156(0.05) 2 & 1.39
\end{array}
$$

The research adopted the stratified random sampling technique which made it possible for all the SMEs in Bwari Area Council of FCT Abuja to be represented in the sample size 
determined above. This research made use of primary data. This was obtained from a sample of SME- operators which was drawn from Bwari Area Council of FCT Abuja. A pilot test was conducted in Kuje Area Council of FCT Abuja using questionnaire for a period of two (two) weeks. The data collected for this study were analyzed using different statistical procedures. The Bio-data variables of the respondents were subjected to simple percentages. This was because it could easily be understood with simple percentages than with any other statistical tools. However, the null hypotheses were tested using Ordinary Least Square (OLS) regression through the aid of SPSS (Version) 23 to ascertain if there existed significant effect or not. Osamuota (2007) noted that it has the advantage of being used to determine the relationship existing between dependent and independent variables, For the purpose of finding the strength of the relationship between taxation as the dependent variable and asset growth, return on assets, working capital and staff recruitment as independent variables, multiple regression analysis was adopted for analysing the null hypothesis of the study. The functional relationship is given as follows.

Tax $=\mathrm{f}($ Asg, Roa, Wca, Src

$$
\text { . }
$$

With the aid of this equation the study arrived at a model which is presented as

follows

Taxi $_{t}=\beta 0+\beta 1$ Asgi $_{t}+\beta 2$ Roai $_{t}+\beta 3$ Wcai $_{t}+\beta 4$ Srci $_{t}+\mathrm{Ui}_{\mathrm{t}}, \quad \ldots \quad \ldots \quad \ldots$

Where, Tax = Taxation of SMEs which is measured by response from questionnaires. Asg=Asset growth measured by response from questionnaires. Roa=Return on assets is measured by response from questionnaires. Wca=Working capital as measured by response from questionnaires. $\mathrm{Src}=\mathrm{Staff}$ recruitment as measured by response from questionnaires. Bo is the intercept while B1-4 is the coefficient of the independent variables.

\section{Data Presentation and Analysis}

The main objective of the study is to examine the effect of business performance on taxation of SMEs in Bwari Area Council of FCT, Abuja, Nigeria. This Section presents the results of data collected and the results interpreted in relation to the stated hypothesis. The dependent variable of this study is taxation (Tax) while the independent variables are Asset growth (Asg), Return on assets (Roa), working capital (Wca) and Staff recruitment (Src).

Table 1 presents a summary of the bio-data of sampled respondents in terms of their demographic (sex, age academic qualifications and working experience) and other related issues. The table indicates that out of the 102 valid responses received, $68 \%$ were from the male respondents, while the remaining $32 \%$ were from the females. This suggests the predominance of males in the operation and management of SMEs in Bwari Area Council of FCT, Abuja.. A possible explanation of this could be that males have traditionally been more engaged in businesses including SMEs operation and management

The table also conveys information on the age distribution of the respondents. It reports that the predominant age group falls between 25-35 years representing 50\% of the respondents. The next largest age group was 35-44, representing 30\% of the respondents. These statistics suggest that about $80 \%$ of the respondents are in their prime age.

Table 1 also sets out the working experience of the respondents, the dominant group is workers who have between 11-15 years working experience and it makes up $49 \%$ of the respondents. This group is closely followed by those with 5-10 years working experience making $35 \%$ of the respondents. These statistics reveal that the staff that responded to the questionnaire has working experience to respond to the issues raised in the questionnaires.

Furthermore, the table shows the educational qualification of the respondents. The highest group was that of respondents having OND (Ordinary National Diploma) which is $70 \%$ of the respondents. This was followed by those with B.Sc. (Bachelor of Science) degree which covers $20 \%$ of the respondents. The implication of this information is that most of the 
operators and mangers of these SMEs are not very educated to appreciate the effect of taxation on performance of SMEs in Bwari Area Council of FCT, Abuja.

Table 1. Demographic and other related issues of respondents

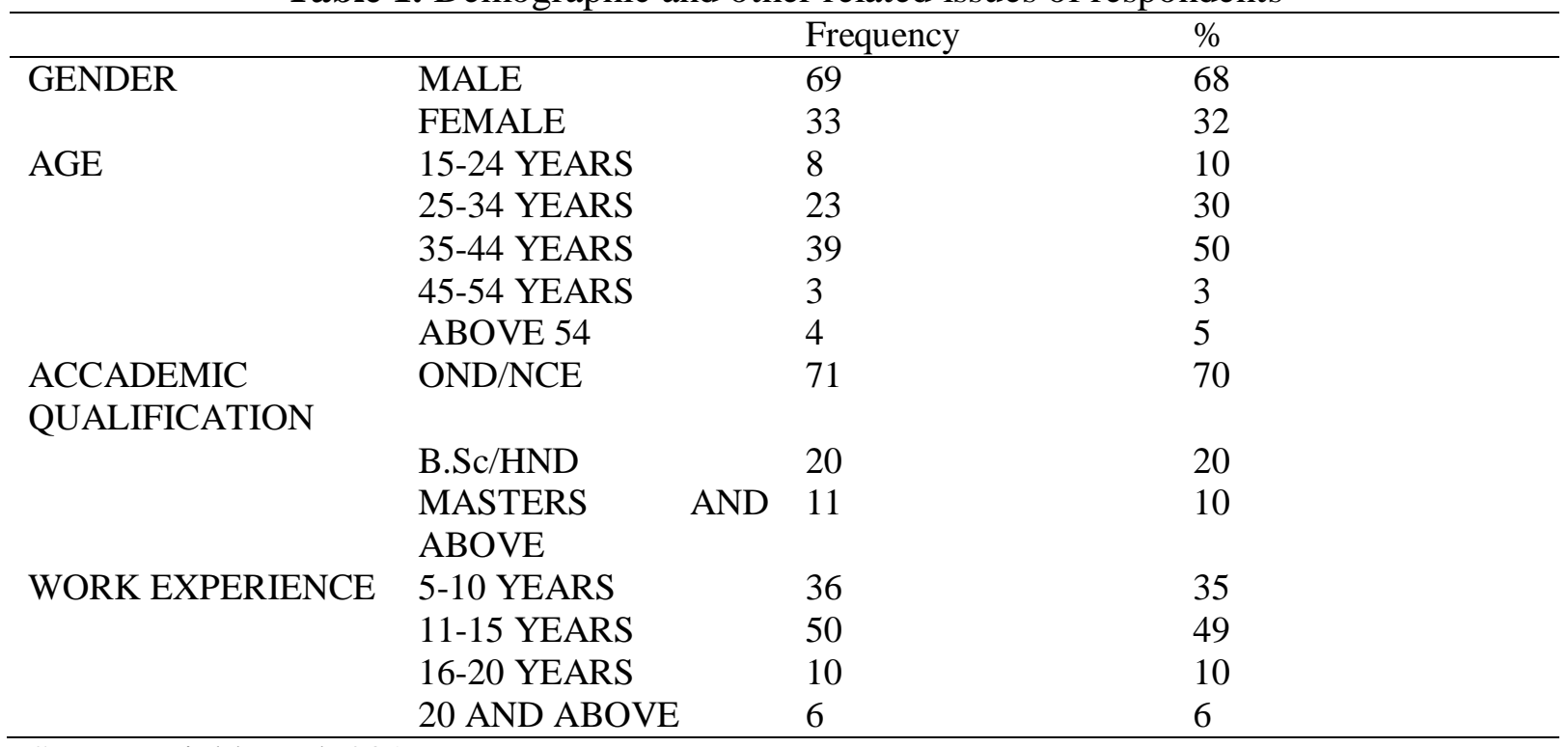

Source. Field work 2019

Table 2 shows the summary statistics of the dependent and independent variables in terms of the mean, standard deviation, minimum and maximum values. Taxation (Tax) by SMEs in Nigeria has a mean of 16.735 with a standard deviation of 4.077, a minimum of 9 and a maximum of 20 suggesting that there is wide dispersion on taxation of SMEs in Bwari Area Council of FCT, Abuja Nigeria. This implies that some of the SMEs are paying taxes more than the others than others and this has a lot of implication on revenue of Bwarri Area Council FCT, Abuja because it may not have enough money to embark on developmental projects of the Area Council to meet its infrastructural needs

Table 2. Descriptive statistics of variables

\begin{tabular}{llllll}
\hline Variables & Obs & Mean & Std Deviation & Minimum & Maximum \\
\hline Tax & 102 & 16.735 & 4.077 & 9 & 20 \\
Asg & 102 & 14.323 & 3.920 & 5 & 20 \\
Roa & 102 & 14.313 & 2.723 & 8 & 20 \\
Wca & 102 & 14.480 & 5.058 & 7 & 20 \\
Src & 102 & 15.078 & 2.899 & 7 & 20 \\
\hline
\end{tabular}

Source, Field work 2017 (STATA 14 output from Appendix A)

Asset growth (Asg) has a mean of 14.323 with a standard deviation of 3.920 , a minimum and maximum value of 9 and 21 respectively. This suggests a wide dispersion in asset growth of SMEs in Bwari Area Council of FCT, Abuja, Nigeria. This is because some of the SMEs are growing in terms of assets acquisition than others. Also, Return on assets had a mean and standard deviation values value of 14.313 and 2.723 respectively, implying that there is a wide disparity in return on assets by SMEs in Bwari Area Council of FCT, Abuja, Nigeria. This is because some of the SMEs make are making profits more than others. Working capital had a mean value of 14.480 and a standard deviation of 5.058, implying that that there is a wide disparity in usage of working capital by SMEs in Bwari Area Council of 
FCT, Abuja, Nigeria because some of the SMEs have working capital than others in their business operations. Staff recruitment had a mean value of 15.078 and standard deviation of 2.899 with minimum and maximum values of 7 and 20 respectively implying that that there is a wide disparity in staff recruitment by SMEs in Bwari Area Council of FCT, Abuja Nigeria because some of the SMEs recruit more staff than others in their business performance.

The correlation between the dependent and independent variables are presented in table 3 and it showed that there was a positive correlation between the dependent variable (Tax) and all the independent variables of the study.

Table 3. Correlation Matrix of Dependent and Independent Variables

\begin{tabular}{lcccccc}
\hline Variables & Tax & Asg & Roa & Wca & Src & VIF \\
\hline Tax & 1.000 & & & & & \\
Asg & 0.259 & 1.000 & & & & 1.42 \\
Roa & 0.449 & 0.432 & 1.000 & & & 1.42 \\
Wca & 0.279 & 0.505 & 0.530 & 1.000 & & 1.69 \\
Src & 0.345 & 0.202 & 0.193 & 0.3199 & 1.000 & 1.12 \\
\hline
\end{tabular}

Source, Field work 2019 (STATA 14 output from Appendix A)

This implies that as the level of use of assets growth, return on assets and working capital, staff recruitment increase the level of taxation by SMEs in Bwari Area Council of FCT, Abuja. Kaplain (1982) as cited in Hussain, Islam and Andrew (2006) suggested that multicollinearity may be a problem when the correlation between independent variables is 0.9 and above where as Emory (1982) considered more than 0.80 to be problematic. Therefore, it was evident from the above table that the magnitude of the correlation amongst the explanatory variables generally indicates no severe multicollinearity problems in the study because the highest correlation coefficient is 0.53 between Roa and Wca. To determine the presence of collinearity problem, a Variance Inflation Factor (VIF) test was carried out and the results provided evidence of the absence of collinearity because the results of the VIF test ranged from a minimum of 1.12 to a maximum of 1.69 and a mean of 1.42 . VIF of 5.00 can still be a proof of absence of collinearity (Neter, Kutner, and Nachtsheim\& Wasserman 1996. Furthermore, the Durbin Watson statistics of 1.279 indicates the absence of first order serial correlation of the variables inside the error term of the model. The regression results of Ordinary least square (OLS) are presented in table 4.

Table 4. Regression Result (OLS)

\begin{tabular}{llll}
\hline Ind. Variables & Coefficients OLS & T- Values OLS & P-Values OLS \\
\hline Constants & 9.58 & 7.54 & 0.000 \\
Asg & 0.305 & 0.56 & 0.578 \\
Roa & 0.295 & 3.78 & 0.000 \\
Wca & -0.321 & -0.41 & 0.683 \\
Src & 0.194 & & 2.97 \\
R-Squared & 0.2734 & & 0.004 \\
Adjusted R-Squared & 0.2435 & & \\
F-Value & 9.13 & \\
P-Value F & 0.0000 & \\
Durbin Watson & \multicolumn{2}{c}{1.276} & \\
\hline
\end{tabular}

Source, Field work 2017 (STATA 14 and SPSS 22 output from Appendix A) 
From the regression result, the coefficient of determination (R-Square) with a value of 0.273 signifies that about $27 \%$ of the total variations in financial mitigation of SMEs in Bwari Area Council of FCT, Abuja has been explained by the explanatory variables taken together. The adjusted R-Square shows that even after adjusting for the degree of freedom, the model could explain about $24.35 \%$ of the total variation in taxation of SMEs in Bwari Area Council of FCT, Abuja, while the rest $75.65 \%$ was explained by other factors not captured in the model.

From the empirical results of the regression analysis above on the basis of the overall statistical significance of the model as indicated by the F-statistics, it was observed that the overall model was statistically significant since F-Change is 9.13. Also since the p-value of 0.000 for F- change was less than $5 \%$ level of significance, which implies that there was a significant linear relationship between the dependent variable of taxation on SMEs in Bwari Area Council of FCT, Abuja and the explanatory variables (asset growth, return on assets, working capital and staff recruitment).

\section{Discussion}

\subsection{Test of Hypotheses and Discussion of Findings}

The hypotheses of the study were tested and the results are shown in the regression table 4 above.

Hypothesis 1 states that asset growth has no significant effect on taxation of SMEs in Bwari Area council FCT, Abuja.

Table 4 shows that asset growth has positive coefficient and p-values of 22.43 and 0.56 respectively indicating that asset growth has a positive and insignificant effect on taxation of SMEs. The implication of this is that as asset growth increases the level taxation of SMEs in Bwari Area Council of FCT, Abuja also increases. From the table it is observed that the probability value of $0.56 \%$ is more than $0.05 \%$ level of significance $(0.56 \%>0.05 \%)$ and this calls for failure to reject the null hypothesis. This finding is consistent with the study conducted by Rosen, Carroll and Douglas (2001); Ojeka (2011) who found that individual income taxes exerted a negative, statistically and quantitative significant influence on firm growth rates.

Hypothesis 2 states that return on assets has no significant effect on taxation of SMEs in Bwari Area council FCT, Abuja.

Considering return on assets, the OLS estimates that it has a positive and significant effect on taxation of SMEs in Bwari Area Council of FCT, Abuja, with coefficients and pvalues of 0.295 and 0.000 respectively. The implication of this is that as return on assets increases taxation of SMEs in Bwari Area Council of FCT, Abuja also increases. From the table it is also observed that the probability value of $0.000 \%$ is less than $0.05 \%$ level of significance $(0.000 \%<0.05 \%)$ and thus, based on this finding the study rejects the null hypothesis. This finding is not in tandem with that of Were (2011) who concluded that presumptive tax negatively affects the profitability of SMEs,

Hypothesis 3 states that working capital has no significant effect on taxation of SMEs in Bwari Area council FCT, Abuja.

Furthermore, the OLS agrees that working capital has a positive and significant effect on taxation of SMEs in Bwari Area Council of FCT, Abuja at 1\% confidence level with coefficient and p-values of 0.321 and 0.683 respectively. This implies that as the level of working capital increases the level of SMEs' taxation also improves. From the table it can be seen that the probability value of $0.683 \%$ is more than $0.05 \%$ level of significance $(0.683 \%$ > $0.05 \%$ ) and based on this finding the study fails to reject the null hypothesis. This finding 
corroborates that of Mika, Andrew and Shiv (2012) who found that tax payment is among the outflows of cash from the business which reduce the purchasing power of an enterprise which also reduces working capital.

Hypothesis 4 states that staff recruitment has no significant effect on taxation of SMEs in Bwari Area council FCT, Abuja.

Considering staff recruitment, the OLS estimates that it has a positive and significant effect on taxation of SMEs in Bwari Area Council of FCT, Abuja at 1\% confidence level with coefficient of 0.194 and p-values of 0.004 . This implies that as staff recruitment improves the level of taxation also improves. From the table, the probability value of $0.004 \%$ is less than $0.05 \%$ level of significance $(0.004 \%<0.05 \%)$ and based on this finding the study rejects the null hypothesis. This finding opposes that of Onias, Mayani, Hove, Chinseri and Mundzura (2014) who found that $67.5 \%$ of respondents agreed that presumptive tax negatively affected their profits and ability to recruit more staff.

\subsection{Summary of the Study}

The main findings of the study are summarized as follows:

Asset growth has a positive and insignificant effect on taxation of SMEs in Bwari Area Council of FCT, Abuja. This implies that as asset growth increases, it leads to corresponding positive increase in taxation of SMEs but it is not significant.

Return on assets has a positive and significant effect on taxation of SMEs in Bwari Area Council of FCT, Abuja. This implies that as the profit of SMEs increase taxation also increases. Working capital has a negative and insignificant effect on SMEs finances in Bwari Area Council of FCT, Abuja. The implication of this is that as working capital of SMEs increase, payments of taxes by SMES reduce. Staff recruitment has a positive and significant effect on taxation of SMEs in Bwari Area Council of FCT, Abuja. This shows that as staff recruitment of SMEs increase, they are able to pay more taxes.

\section{Conclusion}

The following are conclusions that are drawn from the findings of the study

The study concludes that asset growth has no significant effect on taxation of SMEs in Bwari Area Council of FCT, Abuja. The study also concludes that return on assets has significant effect on taxation of SMEs in Bwari Area Council of FCT, Abuja. Similarly, the study concludes that working capital has a negative and insignificant effect on taxation of SMEs finances in Bwari Area Council of FCT, Abuja. Furthermore, the study concludes that staff recruitment has a positive and significant effect on taxation of SMEs finances in Bwari Area Council of FCT, Abuja. Finally, based on the bio-data of the respondents it was concluded that most of the managers and operators of the SMEs in Bwari Area Council of FCT, Abuja are in their prime age and that they are not very educated in terms of acquisition of tertiary education.

\section{Recommendations}

The following recommendations were drawn based on the conclusions of the study.

Operators and managers of SMEs should be acquiring only necessary assets for production to enable them pay more taxes in Bwari Area Council of FCT, Abuja.

SMEs should engage in cost saving measures regularly to enable them make more profits for higher payment of taxes in Bwari Area Council of FCT, Abuja.

SMEs should maintain an optimal working capital to enable them meet up their payment of taxes in Bwari Area Council of FCT, Abuja. 
SMEs should engage necessary staff to enable them make more profits for more remittance of taxes in Bwari Area Council of FCT, Abuja.

Government should provide special and appropriate grants and tax incentives to SMEs which provide their own basic infrastructures like power, road and water. This will go a long way in reducing SMEs cost of production and make them more competitive.

\section{References}

Ande T. (2005). Positioning the Nigerian tax system for social and economic development. Journal of the Nigerian Accountant, 49 (2) 31-56

Aremu, M. A., \& Adeyemi, S. L. (2011). Small and Medium Scale Enterprises as survival strategy for employment generation in Nigeria. Journal of Sustainable Development, 4(1), Retrieved 2017-03-27 from www.ccsenet.org/jsd

Appah, Y (2010). Estimating the growth-maximizing tax rate for Cote d'Tvoire, 1960-2007. Journal of Economic and International. Finanance,2 (9) 164-174.

Chipeta,C. (2002). The Second Economy and Tax Yield in Malawi. Research Paper No.113. African Research Consortium: Nairobi.

Derwent, J. (2000). Diminishing the Barriers: A pan-European Survey on Use of Patents in SMEs.

Devi, S.S. \& Samujh, R. H. (2010). Accountant as providers of support and Advice to SMEs in Malaysia. ACCA Research report 118.

Emory, E. 1982. Business Research Methods. Homewood, IL: Irwin

Ezeife, G.P. (1988). Problems and Prospects of small scale industries in a Design for industrial Revolution. An unpublished seminar paper, Anambra State.

Farzbod, J. (2000). Investigation of the effective factors in the tax efficiency. Unpublished Master's Thesis, Government Management Training Center, Tehran.

Gunter, V. (2005). The New SME definition: User guide and model declaration. Enterprise and industry publication. 1-26, retrieved 24/03/2017. http://ec.europa.eu/enterprise/policies/files/sme-definition/smeuser-guide-en.pdf

Hossain, M., Islan K. \& Andrew J. (2006) Corporate Social and Environmental Disclosure in Developing Countries: Evidence from Bangladesh. Proceeding of the Asian Pacific Conference on International Accenting Issues Hawaii October.

ICAN (2010). Strategic Financial Management. Study Pack, Lagos: VI Publishing

International Tax Dialogue (2007). Taxation of SMEs. Background Paper for the International Tax Dialogue Conference, Bueons Aires.

Kajang, Y.G., David, G.J. \& Jatau, A.A. (2004). Research and Statistics Made Simple In Education. Plateau: Waris Printing Press.

Lucas, M., Prowle, M., \&Lowth, G. (2013). Management Accounting Practices (UK) SmallMedium-sized Enterprises (SMEs), Charterd Institute of Management Accountant (CIMA), 9(4), 1-13.

Manukaji I.J. (2018). Effect of Tax Structure on Economic Growth in Nigeria, International Journal of Innovative Finance and Economics Research, 6 (1) 1-11

Masafo, A. (2009). "Globalization of Production and Competitiveness of Small and Medium Size Enterprises in Asia and Pacific: Trendand Prospects". Publication of United NationMirrlees JA (1971). An exploration in the theory of optimum income taxation. Journal of economic Review, 38 (2) 175-208.

Mika, M., Andrew, H., \& Shiv, K. (2012). Study of Tax System Impact On The Growth of Small and Enterprises: With Reference To Shinyanga Municipality, Tanzania. Unpublished MBA Thesis. Mzumbe University Dar Es Salaam, Tanzania. 
Musgrave, R. A., \& Musgrave, P. B. (1994), Public Finance in Theory and Practice, Tata Oates,

Neter, J., Kutner, M. H., Nachtsheim, C. J. \& Wasserman, W. (1996). Applied Linear Statistical Models, Irwin Company Inc., Chicago, U.S.A

Nweze, S.M (2007): Tax evasion problems in Nigeria. A critique Niger Accountwool bridge press.

Obamuyi, T. M. (2007). An Exploratory Study of Loan Delinquency among Small and Medium Enterprise (SMEs) in Ondo State of Nigeria.Labour and Management Development Journal, 8 (2), 30-45.

Ojeka, A., \&Mukoro, O. O. (2011). International Reporting Standard (IFRS) and SMEs in Nigeria: Perceptions of Academic. International Journal of Research in commerce \& Management, 2, (1), 13-20.

Okwara, C. C \& Amori, O. M (2017). Impact of Tax Revenue on Economic Growth in Nigeria. International Journal of Advanced Scientific Research , 2 (2) 25-40

Olaofe, I.A. (2010). Research for Academic Growth, Zaria: ABU Press limited.

Osamuata, O. (2007). Research and Statistical Methods In Social Sciences and Humanities. African-Fep Publishers Limited. Onitsha.

Oyebode S, (2010). Income taxes and economic performance in Kenya. A research paper submitted to the University of Nairobi, school of economics, in partial fulfilment of the requirements for the award of Masters of Arts degree in Economics.

Ozo Eson, Y, (2005), Fiscal Federalism in Nigeria, Grent A P Express Publishers Limited, Nsukka.

Ojeka, S. A. (2011). Tax Policy and the Growth of SMEs: Implications For The Nigerian Economy. Research Journal of Finance and Accounting, 2 (2) 25-37

Onias. Z., Manyani. O., Hove. N., Chiriseri. I. \& Mudzura, M. (2014). The Effectiveness of presumptive tax and its impact on profitability of SMES in Zimbabwe. Case of Commuter Transport Operators In Bindura. Research Journal of Commerce 2(7) 56-68

Patrick U.\& Chiedu, C.O. (2016). Effect of Tax Revenue on Economic Growth in Nigeria International Journal of Social Sciences and Management Research, 4 (2) 36-50

Rosen, H., Carroll R., \& Douglas., R. (2000). .Income taxes and entrepreneurs. Use of labour. Journal of LabourEconomics 18 (2), 324-351.

SMEDA. (2007). Developing SME Policy In Pakistan. SMEDA

Tashie, MA (2014). The effect of tax incentives on economic growth in Kenya. A research projectsubmitted in partial fulfilment of the requirements for the award of the degree in Masters of science in finance, university of Nairobi.

Tomlin, B. (2008). Cleaning hurdles: key reform to make small business more successful. (Commentary No.264). Toronto, Ontario CD. Howe Institute. www.cdhoweorg/pdf/commentary 264.pdf

Vasak, S. (2008). Small, Medium and Large Enterprises. USAID business climate reform. www.pdf.usaid.gov/pdf doc/DNADO675.pdf

Weichenriedev, A.J. (2007). Survey on the taxation of small and medium size enterprises: draft report on responses to questionnaire .organization for economic cooperation and development website. www.oecd.org/dataoecd! 52/39597756.pdf

Were, F. (2011). Presumptive Income Tax System and Profitability of SMES in Uganda A Case Study. Nakawa Division. Dissertation at Makerere University Uganda.

Yoabin, S. (2007, October). "Tax, Small Business, Growth: Effect of Taxation on Investment and Cross-Border Trade". Paper Presented at the ITD Conference on Taxation of SMEs. 